УДК 378.146-057.875:61

DOI 10.11603/me.2414-5998.2020.3.10888

В. Є. Кондратюк

ORCID https://orcid.org/0000-0002-4891-2338

ResearcherID B-5960-2019

Scopus Author ID 57194008997

С. Г. Шевчук

О. А. Бичков

ORCID https://orcid.org/0000-0002-6820-1736

ResearcherID AAO-8695-2020

Scopus Author ID 56350692700

I. А. Палієнко

ORCID https://orcid.org/0000-0001-9939-7316

ResearcherID AAO-8612-2020

Scopus Author ID 6602812551

Національний медичний університет імені О. О. Богомольця, Київ

\title{
ВИКОРИСТОВУВАННЯ ОБ'ЄКТИВНИХ ПІДХОДІВ ОЦІНЮВАННЯ ПРАКТИЧНИХ ВМІНЬ НА МОЛОДШИХ КУРСАХ
}

\author{
V. Ye. Kondratiuk, S. H. Shevchuk, O. A. Bychkov, I. A. Palienko \\ O. Bohomolets National Medical University, Kyiv \\ THE USING OF NEW OBJECTIVE ASSESSMENT APPROACHES OF \\ JUNIOR COURSES PRACTICAL SKILLS
}

\begin{abstract}
Анотація. Осучаснення традиційного навчального процесу вимагає впровадження новітніх методів оцінювання знань студентів, особливо володіння професійними навичками на перших етапах клінічної підготовки.

При оцінці знань студентів традиційно більшу увагу приділяють контролю за теоретичними знаннями, бо щоб оцінити практичні навички та вміння, треба більше часу, об’єктивності. При контролі знань студентів слід оцінити ще і комунікативні та когнітивні здібності, що досить важко для викладача, бо відсутня стандартизація в критеріях оцінки, різні за складністю завдання, деякі особистісні особливості студента. Сьогодні слід відмітити, що засвоювати практичні навички на пацієнтах стало більш складно, враховуючи етичні норми та права людини, безпеку хворих, тому слід ширше застосовувати нові форми оцінювання практичних вмінь студентів, їх вміння володіти методами обстеження пацієнтів.

Розглянуто організацію проведення ОСКI-1 і його значення в оцінюванні клінічних практичних навичок студентами молодших курсів. ОСКI-1 спрямований на перевірку практичних вмінь і знань студентів з пропедевтики внутрішньої медицини, загальної хірургії та педіатрії. Даний іспит дозволяє об'єктивно оцінити вміння виконувати практичні навички з обстеження пацієнта, проведення СЛР, первинної обробки рани, визначення групи крові та оцінити результат. Станції збору анамнезу в терапевтичного хворого та хворого хірургічного профілю дають можливість оцінити комунікативні навички студента, а підсумувати і визначити провідний синдром - частково дозволяє оцінити і теоретичні знання з предмета. Цей іспит є об’єктивним, викладач-спостерігач не втручається у виконання завдання певної станції, не впливає на проведення цього іспиту, лише оцінює за закритим чек-листом. Форма проведення ОСКІ залишається передовою, бо послуговує не тільки як оцінка клінічних знань і вмінь, але і як засіб корекції навчального процесу.

Перший досвід застосування ОСКI-1 на молодших курсах приніс задоволення викладачам і студентам, він стимулює всі сторони навчального процесу до подальшого самовдосконалення у здобутті знань 3 клінічного обстеження пацієнтів.

Ключові слова: компетентність; практичні вміння; об’єктивна оцінка.

Abstract. The modernization of the traditional educational process requires the introduction of new methods of assessment of students' knowledge, especially the acquisition of professional skills during the first stages of clinical training.

When assessing students' knowledge, more attention is traditionally paid to the control of theoretical knowledge, because to assess practical skills and abilities, it takes more time, objectivity. In the control of students' knowledge the communicative and cognitive abilities should also be assessed, which is quite difficult for the teacher, because there is no standardization in the assessment criteria, different in complexity of the task, some personal characteristics of the student. Today it should be noted that it has become more difficult to acquire practical skills in patients, given ethical norms and human rights, patient safety, so new forms of assessment of students' practical skills, their ability to master the methods of examining patients should be used more widely.
\end{abstract}

( ) В. Є. Кондратюк, С. Г. Шевчук, О. А. Бичков, І. А. Палієнко 
The organization of OSCE- 1 and its importance in the assessment of clinical practical skills by junior students are considered. OSCE-1 is aimed at testing the practical skills and knowledge of students in propaedeutics of internal medicine, general surgery and pediatrics. This exam allows you to assess the ability to perform practical skills in examining the patient, CPR, primary wound treatment, blood group determination and evaluate the result. Anamnesis collection stations in the therapeutic patient and the patient of the surgical profile provide an opportunity to assess the student's communication skills, and to summarize and determine the leading syndrome partially allows to assess the theoretical knowledge of the subject. This exam is objective; the teacher-observer does not interfere in the performance of the task of a particular station, does not affect the conduct of this exam, only evaluates on a closed checklist. The form of OSCE remains advanced, as it serves not only as an assessment of clinical knowledge and skills, but also as a means of correcting the educational process.

The first experience of using OSCE-1 in junior courses brought satisfaction to teachers and students; it stimulates all aspects of the educational process to further self-improvement in acquiring knowledge of clinical examination of patients.

Key words: competence; practical skills; objective assessment.

Вступ. Суспільство, що живе і розвивається в XXI столітті, потребує нових висот і досягнень у різних сферах життя, особливо соціальної спрямованості. В Україні продовжується реформування медицини, розробляються новітні підходи до забезпечення населення якісною медичною допомогою, потребує і осучаснення спеціальна освіта. Розвиток медичної освіти $є$ важливим для оновленого підходу в медичній сфері, зазвичай від якості освіти лікаря залежить якість медичних послуг для пацієнтів. Слід зазначити, що осучаснення медичної освіти - це не тільки створення нових планів і програм. Готуючи висококваліфікованого лікаря, є потреба в модернізації освіти, застосуванні новітніх педагогічних технологій, концепцій, методів навчання, системи оцінювання знань і навичок студентів.

Мета статті - поділитися досвідом проведення об'єктивного структурованого клінічного іспиту у студентів НМУ імені О. О. Богомольця після III курсу.

Теоретична частина. Одним із сучасних напрямків є компетентнісний, спрямований на формування основних фахових і соціальних компетенцій, які дозволяють використовувати знання найефективніше за різних умов, постійно навчатися та покращувати свій професійний рівень. Національний медичний університет імені О. О. Богомольця приєднався до Болонської угоди та надає освітні послуги за Європейською кредитно-трансферною системою (ECTS), ключовими положеннями якої є поняття компетентності. Нові програми навчання передбачають збільшення ролі самостійної роботи студентів, індивідуалізації навчання, взаємозв'язку академічних і практичних вмінь, застосування ефективної клінічної підготовки [3, 4]. ОСКІ (об’єктивний структурований клінічний іспит) вперше в 1975 р. запровадив R. M. Harden для атестації та сертифікації лікарів. Він спрямований на оцінку лікарської компетентності [2]. В наш час багато країн використовує цей іспит для оцінювання професіональних компетентностей.
Ми ознайомилися з досвідом різних вишів, які впродовж довгого часу використовують ОСКІ [1]. Так, вважають, що ОСКІ не може бути лише єдиним оціночним інструментом для визначення професіональної компетентності, навіть зважаючи на його структурованість та об'єктивність, але значущість іспиту повинна бути високою в рейтингу серед інших методів оцінювання.

За недолік автори вважають низьку проінформованість студентів про форму, мету та цілі клінічного іспиту, невідповідність навчальних програм вимогам ОСКІ. Для створення структурованості та об'єктивності необхідно багато складових, таких, як: екзаменатори та стандартизовані пацієнти, розроблені заздалегідь навчальні програми та методи оцінювання, які повинні відповідати цілям і меті OCKI-1. Закриті чек-листи повинні об'єктивно оцінювати виконання кожної станції, бути валідними. Окрема і дуже важлива тема підготовка стандартизованих пацієнтів, які повинні «грати» роль певного пацієнта, але однакова для всіх студентів, що складають іспит. Повинна існувати і загальна оцінка, яка буде свідчити про доцільність та ефективність іспиту після III курсу. Також дуже важливо таким чином підсумувати результати OCKI-1, щоб вони спрямовували студентів на покращення своїх знань на наступних етапах навчального процесу.

При оцінці знань студентів традиційно більшу увагу приділяють контролю за теоретичними знаннями, бо щоб оцінити практичні навички та вміння, треба більше часу, об’єктивності. При контролі знань студентів слід оцінити ще і комунікативні та когнітивні здібності, що досить важко для викладача, бо відсутня стандартизація в критеріях оцінки, різні за складністю завдання, деякі особистісні особливості студента. Сьогодні слід відмітити, що засвоювати практичні навички на пацієнтах стало більш складно, враховуючи етичні норми та права людини, безпеку хворих, тому слід ширше застосовувати нові форми оцінювання практичних вмінь студентів, їх вміння володіти методами обстеження пацієнтів. 
З урахуванням складностей, таких, як стандартизація завдань, використовування новітніх надійних технологій, об'єктивізація оцінки, повторюваність результатів у світі, використовується об'єктивний структурований клінічний іспит (ОСКI). В нашому університеті впродовж останніх 3 років був розроблений та апробований іспит після 3 курсу OCKI-1, який спрямований на перевірку практичних вмінь і знань студентів 3 пропедевтики внутрішньої медицини, загальної хірургії та педіатрії.

Ми врахували досвід та здобутки європейських медичних університетів, зокрема Польщі. Адміністрація НМУ запросила доктора Міхала Новаковського, в. о. директора відділу медичної дидактики з Ягеллонського університету (місто Краків), який прочитав ряд лекцій та провів заняття з викладачами, щоб роз'яснити суть та мету, організаційні питання з проведення ОСКІ та поділитися власними здобутками з цього іспиту. В подальшому факультет підвищення кваліфікації викладачів НМУ провів цикли занять для викладачів, що могло забезпечити об' єктивність та надійність проведення клінічного іспиту. Викладачі НМУ знайомились із проведенням ОСКІ в місті Кракові. Після обговорення на кафедрах, та засіданнях ЦМК з дисциплін, були обговорені сценарії та регламенти проведення ОСКI-1 з позиції викладання клінічних дисциплін в НМУ. В університеті використовують 12 тематичних станцій з різними клінічними питаннями, 3 них -5 терапевтичного спрямування, 6 - хірургічного і 1 - педіатричного. Відповідно до цих практичних навичок складені конкретизовані лаконічні завдання для іспиту, які розподілені на основні групи: збір скарг і анамнестичних даних у пацієнта, фізикальні обстеження пацієнта, інтерпретація результатів лабораторно-інструментальних методів обстеження, діагностичні та лікувальні маніпуляції на фантомах, комунікативні навички.

Переважно на кожну станцію відведено 5 хв, і 2 станції по 10 хв, це станції з розпитування стандартизованого пацієнта та визначення провідного синдрому, щоб перевірити, в тому числі, комунікативні навички студента. Зважаючи на велику кількість студентів та тривалість певних маніпуляцій, станції тривалістю 10 хв продубльовані, відбувається одночасно з різними викладачами-оцінювачами в аналогічних стилізованих приміщеннях. Всього OCKI-1 триває одну годину 10 хв. На кожній станції студент має вибір з декількох варіантів завдань, що були відповідно відібрані та затверджені.
Для проведення ОСКI-1 в університеті виділені спеціальні приміщення, які стилізовані під кабінет лікаря, маніпуляційну та обладнані необхідними атрибутами. При оцінці клінічних навичок використовують муляжі, манекени, що відповідають вимогам виконання певних навичок. Для збирання анамнезу розроблені сценарії по 10 провідних синдромах та підготовлені стандартизовані пацієнти 3 числа студентів старших курсів. Для проведення серцево-легеневої реанімації використовують високотехнологічний манекен, ця станція $€$ обов’ язковою для виконання, її проводить один студент. Станції «реєстрація ЕКГ» та «розшифрування ЕКГ» теж забезпечені необхідною апаратурою та набором ЕКГ-плівок з тем «Аритмія», «Гостре порушення коронарного кровопостачання».

При складанні ОСКI-1 всі студенти отримують індивідуальний маршрутний лист, по дзвонику виконується завдання на кожній станції та по дзвонику за стандартний час закінчується. Це дозволяє уникнути дезорганізації та сутичок, що забезпечує правильний розподіл часу, та студенти не витрачають зайвий час на емоції, сприяє зосередженості та успішному виконанню роботи.

OCKI-1 дозволяє отримати достовірний результат навичок клінічного обстеження пацієнта, має високий ступінь надійності. Перелік цих навичок студенти знають вже на початку навчального року, вивчають їх під час практичних занять, можуть самостійно відшліфовувати їх до рівня автоматизму за допомогою відеороликів, що були створені на кафедрі пропедевтики внутрішньої медицини № 1 НМУ імені О. О. Богомольця, та алгоритмів виконання кожної окремої практичної навички, з якими можна ознайомитися на сайті НМУ та YouTube. Напередодні іспиту проводяться групові та індивідуальні консультації в межах підготовки до клінічного іспиту. Деканати проводять інструктажі, обговорення змісту мети та регламенту OCKI-1. Формують групи для складання іспиту за алфавітним принципом.

Дуже важливо, що ОСКІ-1 проводяться різними мовами: українською, російською та англійською, а також всі супровідні матеріали декількома мовами.

Об’єктивна оцінка за виконання завдань кожної станції ставиться на підставі чек-листа закритого типу. Чек-лист оформлює викладач-спостерігач, який не має права втручатися у виконання завдання станції. Викладачі беруть участь в іспиті за графіком, позмінно, можуть кожний раз змінювати станцію. Перед іспитом викладач знайомиться 
3 чек-листом, з розбаловкою окремих етапів маніпуляції, 3 наявністю питань, які $є$ «червоними прапорцями», та загальною сумою балів за кожну станцію. Особлива увага приділяється викладачам, які будуть екзаменаторами (спостерігачами) і брати участь у складанні ОСКI-1, це найдосвідченіші представники різних клінічних кафедр університету, переважно професори і доценти, що пройшли цикли ФПК саме з організації і проведення іспиту. Слід підкреслити відповідальність голови екзаменаційної комісії за організацію роботи всіх учасників ОСКІ. В тому числі і екзаменаторів, бо навіть запізнення одного спостерігача може призвести до дезорганізації проведення всього іспиту. Після виконання завдання станції викладач вирішує, «склав» чи «не склав» студент, із відповідною позначкою. Після виконання всіх завдань 12 станцій підсумовується результат іспиту екзаменаційною комісією за оціночними індивідуальними листками. Визначається, якщо виконано > 60,5 \% станцій, у тому числі 2 обов’язкових (серцево-легенева реанімація та хірургічна допомога при травмі), у такому випадку студент склав OCKI-1 і може навчатися далі. Станція вважається успішно пройденою за умови набрання студентом $\geq 60,5$ \% балів. Кожна станція OCKI-1 оцінюється в балах. Кожна станція оцінюється закритим чек-листом, маніпуляція розділялася на проміжні контрольні етапи. Викладач-спостерігач ставив позначки про їх виконання, що відповідало певній кількості балів, котрі підраховувались. Оцінювання ОСКI-1 здійснюється за шкалою зараховано/не зараховано.

Для оцінювання результатів іспиту та організації подальшого навчання на відповідних кафедрах, щоб врахувати помилки і сприяти покращенню навчання, комісія продовжує працювати влітку, аналізуючи чек-листи, враховуючи особисту думку екзаменаторів та студентів, з проведенням анонімного анкетування студентів і потім на підсумкових зборах доповідає остаточні загальні та індивідуальні результати складання клінічного іспиту. При цьому оцінюється робота і викладачів, і студентів для більшої об’єктивізації оцінювання результатів. На результат іспиту не впливає саме той чи інший екзаменатор, що теж забезпечує незалежність оцінювання і не впливає на результат іспиту.

Слід відмітити, що більшість викладачів і студентів вважають доцільним проведення клінічного іспиту з обстеження пацієнтів, враховуючи фізикальні та лабораторно-інструментальні методи. Дуже важлива думка студентів, які підкреслюють значущість іспиту для оцінювання практичних знань для кожної особи.

OCKI-1 дозволяє об’єктивно оцінити вміння виконувати практичні навички з обстеження пацієнта, проведення СЛР, первинної обробки рани, визначення групи крові та оцінити результат. Станції збору анамнезу у терапевтичного хворого та хворого хірургічного профілю дають можливість оцінити комунікативні навички студента, а підсумувати і визначити провідний синдром - частково дозволяє оцінити і теоретичні знання з предмета. Цей іспит є об’єктивним, викладач-спостерігач не втручається у виконання завдання певної станції, не впливає на проведення цього іспиту, лише оцінює за закритим чек-листом. Форма проведення OCKI залишається передовою, бо послуговує не тільки як оцінка клінічних знань і вмінь, але і як засіб корекції навчального процесу. Слід на досвіді переконатись, що оціночний чек-лист достовірно оцінює виконання станції.

Але, звичайно, є і труднощі. На нашу думку, повинен бути зворотний зв'язок. Кожний студент повинен знати не тільки оцінку, а й помилки, які він зробив, або не так щось виконав. Ці навички з клінічного обстеження пацієнта він буде використовувати впродовж життя, а на старших курсах виправити помилки буде важче, бо у викладача інша мета. Слід заохочувати студентів до здобуття більшого рівня знань у подальшому.

Велика робота проводиться і напередодні ОСКI. Секретаріат забезпечує кабінети необхідним обладнанням, манекенами, розчинами, рукавичками, серветками і тому подібним, чек-листами, оціночними листками на кожного студента, маршрутними листами, нумеруються станції. Перед початком зміни перевіряється наявність студентів груп, ідентифікація особистості, щоб були ручки, фонендоскопи, тобто готовність студента до іспиту. Голова екзаменаційної комісії в день проведення іспиту, напередодні зміни особисто перевіряє готовність до початку іспиту кожного учасника зміни. Як правило, в нашому університеті це 2 зміни, з 8:00 та 14:00 після іспиту перевіряють наявність усіх чек-листів, оціночних індивідуальних листів та підраховують і оголошують результат іспиту.

Висновки та перспективи подальших досліджень. Перший досвід застосування OCKI-1 на молодших курсах приніс задоволення викладачам і студентам, він стимулює всі сторони навчального процесу до подальшого самовдосконалення у здобутті знань з клінічного обстеження пацієнтів. 
Цей іспит виправдовує себе як об’єктивний метод оцінювання практичних вмінь студента, але потребує продовження роботи з вдосконалення прове-

\section{Список літератури}

1. Алпысова А. Р. Групповой объективный структурированный клинический экзамен как инновационный метод оценки знаний / А. Р. Алпысова, Ю. В. Суббота, Ж. С. Кызырова // Современные проблемы науки и образования. - 2016. - № 1. - С. 1-5.

2. Опыт использования современных образовательных технологий в медицинском образовании / Ф. А. Миндубаева, Н. В. Гитенис, А. М. Евневич [и др.] // Международный журнал экспериментального образования. - 2016. - № 8. - С. 26-28.

\section{References}

1. Alpysova, A.R., Subbota, Yu.V., \& Kyzyrova, Zh.S. (2016). Gruppovoy obyektivnyy strukturirovannyy klinicheskiy ekzamen, kak innovatsionnyy metod otsenki znaniy [Group objective structured clinical examination as an innovative method of assessing knowledge]. Sovremennyye problemy nauki i obrazovaniya - Modern Problems of Science and Education, 1, 1-5 [in Russian].

2. Mindubayeva, F.A., Gitenis, N.V., Yevnevich, A.M., Salikhova, Ye.Yu., \& Kharisova, N.M. (2016). Opyt ispolzovaniya sovremennykh obrazovatelnykh tekhnologiy $\mathrm{v}$ meditsinskom obrazovanii [Experience of using modern educational technologies in medical education]. Mezhdunarodnyy zhurnal eksperimentalnogo obrazova- дення клінічного іспиту. За допомогою складання OCKI-1 можна вносити зміни в навчальний процес і вдосконалювати навчальні плани.

3. Про вищу освіту : Закон України від 01.07.2014 р. № 1556-VII [Електронний ресурс]. - Режим доступу : http://vnz.org.ua/zakonodavstvo/111-zakon-ukrayinyprovyschu-osvitu.

4. Academic primer series: key papers about competencybased medical education / R. Cooney, T. M. Chan, M. Gottlieb [et al.] // Western Journal of Emergency Medicine. - 2017. - Vol. 18 (4). - P. 713-720.

niya - International Journal of Experimental Education, 8, 26-28 [in Russian].

3. Zakon Ukrainy "Pro vyshchu osvitu” vid 01.07.2014 r. № 1556-VII [The Law of Ukraine on Higher Education of 07.01.2014 No. 1556-VII]. Retrieved from: http://vnz.org. ua/zakonodavstvo/111-zakon-ukrayiny-provyschu-osvitu [in Ukrainian].

4. Cooney, R., Chan, T.M., Gottlieb, M., Abraham, M., Alden, S., Mongelluzzo, J., ... Sherbino, J. (2017). Academic primer series: key papers about competency-based medical education. Western Journal of Emergency Medicine, 18 (4), 713-720. 